\title{
Subgroups of young type 2 diabetes in India reveal insulin deficiency as a major driver
}

\author{
Rashmi B Prasad $\mathrm{PhD}^{1}$, Olof Asplund $\mathrm{MSc}^{1}$, Sharvari R Shukla $\mathrm{PhD}^{2,3}$, Rucha Wagh $\mathrm{MSc}^{2}$, \\ Pooja Kunte $\mathrm{MSc}^{2}$, Dattatrey Bhat $\mathrm{MSc}^{2}$, Malay $\mathrm{Parikh}^{4}$, Meet $\mathrm{Shah}^{4}$, Sanat Phatak $\mathrm{DM}^{2}$, \\ Annemari Käräjämäki $\mathrm{MD}^{5}$, Anupam Datta $\mathrm{MD}^{6}$, Sanjeeb Kakati $\mathrm{MD}^{6}$, Tiinamaija Tuomi \\ $\mathrm{PhD}^{1,7,8}$, Banshi Saboo ${ }^{4}$, Emma Ahlqvist $\mathrm{PhD}^{1}$, Leif Groop $\mathrm{PhD}^{1,8}$, Chittaranjan S Yajnik \\ $\mathrm{MD}^{2}$
}

${ }^{1}$ Department of Clinical Sciences, Diabetes and Endocrinology, CRC, Lund University, Malmö SE-205 02, Sweden

${ }^{2}$ Diabetes Unit, Kamalnayan Bajaj Diabetology Research Centre, King Edward Memorial Hospital and Research Centre, Pune 411011, India.

${ }^{3}$ Symbiosis Statistical Institute, Symbiosis International University, Pune 411005, India

${ }^{4}$ Dia Care - Diabetes Hormone Clinic, 1 \& 2, Gandhi Park, L Colony, Ambawadi, Ahmedabad, Gujarat 380015, India

${ }^{5}$ Department of Primary Health Care, Vaasa Central Hospital, Vaasa, Finland; Diabetes Center, Vaasa Health Care Center, Vaasa, Finland.

${ }^{6}$ Assam Medical College and Hospital, AMC Rd, Barbari, Dibrugarh Assam 786002, India

${ }^{7}$ Abdominal Center, Endocrinology, Helsinki University Central Hospital, Research Program for Clinical and Molecular Metabolism, University of Helsinki, Helsinki, Finland; Folkhälsan Research Center, Helsinki, Finland

${ }^{8}$ Institute for Molecular Medicine Finland FIMM, Helsinki University, Helsinki 00290, Finland Corresponding authors:

Rashmi B Prasad, Department of Clinical Sciences, Diabetes and Endocrinology, CRC, Lund University, S-205 02 Malmö, Sweden. E-mail: rashmi.prasad@med.lu.se

Chittaranjan S Yajnik, Diabetes Unit, Kamalnayan Bajaj Diabetology Research Centre, King Edward Memorial Hospital and Research Centre, Pune 411011, India.

Word count: main text: 3919 , abstract: 310 NOTE: This preprint reports new research that has not been certified by peer review and should not be used to guide clinical practice. 
medRxiv preprint doi: https://doi.org/10.1101/2021.05.07.21256703; this version posted May 10, 2021. The copyright holder for this preprint (which was not certified by peer review) is the author/funder, who has granted medRxiv a license to display the preprint in perpetuity.

All rights reserved. No reuse allowed without permission.

\section{Abstract}

Aim/Hypothesis: Five subgroups were described in European diabetes patients using a data driven machine learning approach on commonly measured variables. We aimed to test the applicability of this phenotyping in Indian young-onset type 2 diabetes patients.

Methods: We applied the European derived centroids to the Indian type 2 diabetes patients diagnosed before 45 years of age from the WellGen $(n=1612)$ cohort. We also applied de novo k-means clustering to the WellGen cohort to validate the subgroups. We then compared clinical and metabolic-endocrine characteristics and the complication rates between the subgroups. We also compared characteristics of the WellGen subgroups with those of two young European cohorts ANDIS $(n=962)$ and DIREVA $(n=420)$. Subgroups were also assessed in two other Indian cohorts, Ahmedabad $(\mathrm{n}=187)$ and PHENOEINDY-2 $(\mathrm{n}=205)$.

Results: Both Indian and European young type 2 diabetes patients were predominantly classified into severely insulin-deficient (SIDD) and mild obesity-related (MOD) subgroups, while the severely insulin-resistant (SIRD) and mild age-related (MARD) subgroups were rare. In WellGen, SIDD (53\%) was more common than MOD (38\%), contrary to figures in Europeans (Swedish: $26 \%$ vs $68 \%$, Finnish: $24 \%$ vs $71 \%$ respectively). A higher proportion of SIDD compared to MOD was also seen in Ahmedabad (57\% vs 33\%) and in PHENOEINDY-2 (67\% vs $23 \%$ ). Both in Indians and Europeans, the SIDD subgroup was characterized by insulin deficiency and hyperglycemia, MOD by obesity, SIRD by severe insulin resistance and MARD by mild metabolic-endocrine disturbances. In WellGen, nephropathy and retinopathy were more prevalent in SIDD compared to MOD while the latter had higher prevalence of neuropathy.

Conclusions /Interpretation: Our data identified insulin deficiency as the major driver of type 2 diabetes in young Indians, unlike in young European patients in whom obesity and insulin resistance predominate. Our results provide useful clues to pathophysiological mechanisms and susceptibility to complications in young Indian type 2 diabetes, and suggest a need to review management strategies. 
medRxiv preprint doi: https://doi.org/10.1101/2021.05.07.21256703; this version posted May 10, 2021. The copyright holder for this preprint (which was not certified by peer review) is the author/funder, who has granted medRxiv a license to display the preprint in perpetuity.

\section{Introduction}

Type 2 diabetes has been traditionally considered one disease characterised by both insulin resistance and insulin deficiency. Nevertheless, the disease is heterogeneous [1]. A formal description of five distinct subgroups was proposed in a large Swedish cohort [2] and replicated in other populations [2-5]. These subgroups the severely autoimmune (SAID), severely insulindeficient (SIDD), severely insulin-resistant (SIRD), mild obesity-related (MOD) and mild agerelated diabetes (MARD). The subgroups differed not only with respect to clinical characteristics at diagnosis, but also with pathophysiological mechanisms and susceptibility to complications.

India is referred to as one of the diabetes capitals of the world, and Indian type 2 diabetes patients differ from Europeans in that they develop diabetes at a younger age and are thinner $[6,7]$. Indians also differ in body composition, having higher fat and lower lean proportions at the same BMI [8]. Given the role of adiposity in insulin resistance, it has therefore been assumed that type 2 diabetes in Indians is primarily driven by insulin resistance [9]. However, it is increasingly recognised that insulin deficiency may be a significant driver of diabetes in Indians [10]. Recent studies show that both the increase in the diabetes prevalence and characteristics of these patients vary in different parts of India $[11,12]$. Lean type 2 diabetes is prevalent in India, especially in undernourished regions [13]. Recent studies have shown that subgroups of type 2 diabetes in Indians showed partial concordance with those in Europeans [14, 15].

Type 2 diabetes is diagnosed at a younger age in India and its pathophysiology and heterogeneity warrants further investigation. Younger age at diagnosis has distinct implications for treatment, long-term complications, mortality as well as socioeconomic burden [16]. Therefore, early identification of sub-classes may be vital for appropriate treatment to reduce adverse outcomes [17]. To address this, we implemented the Swedish algorithm [2] to identify subgroups of young Indian type 2 diabetes patients diagnosed before 45 years of age from the WellGen cohort from Pune, India [18]. We then compared Indian and European type 2 diabetes subgroups to obrain information on the relative distributions and characteristics in the two populations. We also performed de novo clustering of patients from the WellGen study, to assess if similar clusters are obtained sans prior hypothesis. Finally, we investigated the subclassification of type 2 diabetes in cohorts from two other geographical regions across India. 
medRxiv preprint doi: https://doi.org/10.1101/2021.05.07.21256703; this version posted May 10, 2021. The copyright holder for this preprint (which was not certified by peer review) is the author/funder, who has granted medRxiv a license to display the preprint in perpetuity.

\section{Methods}

\section{Study population}

\section{WellGen (Pune, Maharashtra, Western India)}

The WellGen Study includes patients visiting the Diabetes Unit, KEM Hospital, Pune and associated clinics for routine diabetes management between 2004 and 2006 [18]. Patients diagnosed with diabetes below 45 years of age using the WHO guidelines were included [1]. Diagnosis of type 2 diabetes was based on clinical criteria: age at diagnosis more than 20 years, no history of ketoacidosis, central obesity (Waist Hip Ratio $>0.80$ in women and $>0.90$ in men), and response to treatment with oral antidiabetic agents. Patients with clinical diagnosis of type 1 diabetes (diagnosis before 20 years of age, history of ketoacidosis, continuous insulin treatment since diagnosis), fibrocalculous pancreatic diabetes (FCPD) or fulfilling criteria for monogenic diabetes were excluded. In total, 1612 patients were included (Table 1).

Clinical information including age, sex, age at diagnosis, family history, and socioeconomic status was obtained through a standardized questionnaire. Height, weight, waist and hip circumferences, and blood pressure were measured using standardized methods $[18,19]$. Fasting plasma glucose, total and HDL cholesterol, triglycerides, and HbAlc were measured using standard laboratory assays as described earlier [18, 19]. Fasting C-peptide was measured by ELISA (Diagnostic Biochem Canade Inc, Ontario, Canada). Fasting glucose and C-peptide measurements were used to calculate HOMA2-B and HOMA2-IR values [20, 21]. Details of treatment (insulin, oral antidiabetic drugs, blood pressure and lipid-lowering medication) were recorded.

Complications: Coronary artery disease (CAD) was defined by ICD 10 codes I20-21, I24, I251 and I253-259. Stroke was defined by ICD 10 codes I60-61 and I63-64. Nephropathy was diagnosed by urine strip albumin measurement by a strip (nil, trace, and + ), and by eGFR calculation ( $\mathrm{ml} / \mathrm{min} / 1.73 \mathrm{~m}^{2}$ body surface area) by MDRD formula ( $>90$ normal, CKD: $90-60$ mild, 60-30 moderate and $<30$ severe). Diagnosis of retinopathy was based on dilated fundus examination performed by an ophthalmologist, classified into NPDR (non-proliferative diabetic retinopathy) and PDR (proliferative diabetic retinopathy). Peripheral neuropathy was diagnosed by Biothesiometer (non-perception of vibration sense at 15 or higher amperes at two or more sites on the feet) (Table 2). 
medRxiv preprint doi: https://doi.org/10.1101/2021.05.07.21256703; this version posted May 10, 2021. The copyright holder for this preprint (which was not certified by peer review) is the author/funder, who has granted medRxiv a license to display the preprint in perpetuity.

\section{Ahmedabad (Gujarat, Western India)}

Patients with clinical diagnosis of type 2 diabetes visiting the DiaCare Clinic, Ahmedabad during 2018-2019 diagnosed below 45 years of age and duration of diabetes less than 2 years were invited to participate and 187 patients consented. Measurements included anthropometry, HbA1c levels, a fasting blood measurement of plasma glucose and C-peptide (MAGLUMI ${ }^{\mathrm{TM}}$ C-peptide (CLIA), Shenzhen, China). Anti-diabetic and other medication history was recorded (Supplementary table 6).

\section{PHENOEINDY-2 (Dibrugarh, Assam, North-east India)}

Patients with clinical diagnosis of type 2 diabetes attending medical outpatients of Assam Medical College, Dibrugarh during 2017 to 2019 if diagnosed below 40 years of age were invited to participate and 205 patients consented. Measurements included anthropometry, HbA1c levels, a fasting blood measurement of plasma glucose and C-peptide (ELISA, Diagnostic Biochem Canade Inc, Ontario, Canada). Anti-diabetic and other medication history were recorded (Supplementary table 8).

\section{ANDIS (Scania, Southern Sweden)}

The ANDIS project comprises newly diagnosed diabetic patients aged $>18$ years in the Scania County, Sweden between 2008 to 2016 [2]. Biochemical and anthropometric measurements and presence of complications were recorded as described before [2]. For the current study, 962 patients diagnosed with type 2 diabetes before 45 years of age were included. We excluded patients with known type 1 diabetes, monogenic diabetes and GAD antibody positivity (so called SAID) to maintain concordance with the WellGen study. The prevalence of complications (diagnosed as described previously [2]) was recorded on average 4.2 years after diagnosis. (Table 2).

\section{DIREVA (Vaasa, Western Finland)}

DIREVA includes 5107 individuals with diabetes recruited from 2009 to 2014 in the Vaasa Hospital District. For the current study, 424 type 2 diabetes patients diagnosed below 45 years of age were included, exclusion criteria were similar to ANDIS. Biochemical and anthropometric measurements have been described before [2]. No treatment or complication data from DIREVA have been included in the current study (Supplementary table 4).

All studies were approved by the local/regional Institutional Ethics Committees, and all subjects gave written informed consent. 
medRxiv preprint doi: https://doi.org/10.1101/2021.05.07.21256703; this version posted May 10, 2021. The copyright holder for this preprint (which was not certified by peer review) is the author/funder, who has granted medRxiv a license to display the preprint in perpetuity.

\section{Statistical methods}

Patients with measurements above or below 5 standard deviations from the mean for the clustering parameters were excluded from the analysis and values outside the limits for HOMA2 calculation (fasting glucose $(\mathrm{FG})<3 \mathrm{mmol} / \mathrm{L}$ or $\mathrm{FG}>25 \mathrm{mmol} / \mathrm{L}$, or C-peptide $<0.2 \mathrm{ng} / \mathrm{ml}$ or C-peptide $>3.5 \mathrm{ng} / \mathrm{ml}$ ) were capped to the proximal upper or lower limits. To perform supervised clustering in relation to the European derived cluster coordinates, phenotypes (age at diagnosis, HbA1c, HOMA2B, HOMA2IR and BMI) were scaled using the same scaling parameters (mean and standard deviation) as described previously [2]. Due to the unavailability of GADA data in the Indian study (WellGen), we only included clusters 2-5 (SIDD, SIRD, MOD and MARD). Patients were assigned to the pre-determined clusters on the basis of which ANDIS cluster they were most similar to, calculated as their Euclidean distance from the nearest cluster centre derived from ANDIS co-ordinates. The nearest centroid method was used to find the nearest centroid (as measured with Euclidean distances) for each patient. This resulted in each patient being assigned to any of the 4 clusters: 2/SIDD, 3/SIRD, 4/MOD or 5/MARD. Given the wide range of duration of diabetes in WellGen, we performed a sensitivity analysis by separately assessing the type 2 diabetes subgroups among those within 5-years of diagnosis and those above.

To perform unsupervised clustering, all previously mentioned variables were used in a separate analysis. Given that the results from the supervised clustering analysis showed a strong bias towards the 2/SIDD and 4/MOD cluster, and the silhouette analysis indicated that two was the most stable number of clusters, we performed k-means clustering into 2 clusters. All phenotypes were scaled to have a mean of 0 and a standard deviation of 1 , this time with scaling parameters derived from the data itself. k-means clustering was then performed separately in females and males using the k-means runs algorithm from the fpc $\mathrm{R}$ package.

\section{Type 1 diabetes risk scores}

In absence of GADA data, we applied validated 'type 1' Genetic Risk Score (GRS) to 560 WellGen participants with available data to estimate the proportion of those carrying autoimmune risk alleles. These patients did not differ from those on whom genotyping was not available (ESM table 5). Positive controls were 261 type 1 diabetic patients as described previously [22]. Negative controls were 461 normal glucose tolerant ( $75 \mathrm{~g}$ oral glucose tolerance test; WHO 1999 criteria) participants from the Pune Maternal Nutrition Study [23]. 
medRxiv preprint doi: https://doi.org/10.1101/2021.05.07.21256703; this version posted May 10, 2021. The copyright holder for this preprint (which was not certified by peer review) is the author/funder, who has granted medRxiv a license to display the preprint in perpetuity. All rights reserved. No reuse allowed without permission.

\section{Genotyping:}

Genome wide genotyping data was generated on WellGen and PMNS participants using Affymetrix SNP 6.0 Chips (Affymetrix, CA, USA) and the Infinium Global Screening Array V1 B37 (Illumina) for type 1 diabetes cohort. QC and Imputation were performed as described in ESM methods. In addition, Sequenom Mass Array technology was used to validate the 9 type 1 diabetes associated SNPs (Supplementary Table 5) with $>98 \%$ success rate in the type 1 diabetes cohort.

GRS: A previously described set of 9 SNPs was used for type 1 diabetes GRS calculations (Supplementary Table 5) [22, 24, 25]. In the absence of genotyping data for rs7454108, a proxy SNP rs3957146 (LD: r2=1, D’=1) was used. The haplotype was constructed using rs2187668+ rs3957146 as described previously [22] and GRS scores were computed on plink using weighted scores. Logistic regression was performed to assess the discriminatory power of GRS between type 1 diabetes and other subgroups. 
medRxiv preprint doi: https://doi.org/10.1101/2021.05.07.21256703; this version posted May 10, 2021. The copyright holder for this preprint (which was not certified by peer review) is the author/funder, who has granted medRxiv a license to display the preprint in perpetuity.

\section{Results}

We first sought to investigate the subgroups of young type 2 diabetes patients in Indian WellGen study and compare them with Swedish subgroups from the ANDIS study.

The WellGen study comprised patients diagnosed with type 2 diabetes before 45 years of age, and all relevant data required for clustering were available on 1624 patients. After applying exclusions, 1612 patients (56\% male) with average age at diagnosis of 40 years, duration of diabetes $\sim 10$ years, and BMI $26.18 \mathrm{~kg} / \mathrm{m}^{2}$ were included. (ESM fig 1, table 1).

For comparison, we selected 962 type 2 diabetes patients (58.9\% male, average age at diagnosis 38.83 years) from the ANDIS study, after excluding 577 patients belonging to cluster 1 (SAID) [2]. The Indian patients were younger at diagnosis, had lower BMI, higher fasting plasma glucose, and lower fasting C-peptide, HOMA2B and HOMA2IR compared to the ANDIS subcohort (Table 1). The proportion of patients on lifestyle management alone, on antidiabetic oral agents and on insulin treatment was broadly similar in both cohorts (Table 2). In the WellGen study, men had a higher prevalence of cardiovascular events, nephropathy and retinopathy compared to women whereas that of neuropathy was higher in women. There was no difference with respect to these complications between men and women in the ANDIS study (Table 2). We did not compare the complication rates between the two cohorts because of difference in duration of diabetes.

\section{SIDD predominant in India, MOD in Sweden}

In the absence of GADA data, we obtained the four expected clusters, albeit with different proportions. In the WellGen study, the severe insulin-deficient SIDD cluster was the largest subgroup (52.8\%), followed by the mild obesity-related MOD (37.7\%), while severely insulin resistant SIRD (1.1\%) and mild age-related MARD (8.4\%) were less common. In a sensitivity analysis, with increasing duration of diabetes (from less than to more than 5y), the proportion of patients in the SIDD subgroup increased (45.5 to 56.9\%) while that in MOD decreased (44.7 to $33.8 \%)($ ESM Table 1).

In the sex-stratified analysis, SIDD (60.6\%) remained the predominant cluster in the men whereas MOD (53.2\%) in women; MARD was more common in men (13.3\% vs $2.1 \%$ ) (Figure 1, Table 3).

Concordant to the diabetes subgroups in ANDIS, Indian SIDD patients had the lowest insulin 
medRxiv preprint doi: https://doi.org/10.1101/2021.05.07.21256703; this version posted May 10, 2021. The copyright holder for this preprint (which was not certified by peer review) is the author/funder, who has granted medRxiv a license to display the preprint in perpetuity.

All rights reserved. No reuse allowed without permission.

secretion (HOMA- $\beta$ ) and the highest glycemia while MOD had the highest BMI. SIRD were the most insulin resistant, whereas MARD were the oldest at diagnosis, with mildest glycemia and lowest degree of insulin resistance (Figure 2, Table 3). These results support the pathophysiological basis for subclassification in a population which has a different genetic and socio-economic background compared to the Swedish.

The distribution of subgroups in ANDIS differed from that of WellGen; MOD was the most predominant cluster (67.56\%), followed by SIDD (26.09\%), SIRD (3.64\%) and MARD (2.70\%). These distributions were similar in men and women (Figure 1, Table 3). The pathophysiological characteristics in these young Swedish type 2 diabetes patients were similar to those in the parent ANDIS cohort (Figure 2, Table 3).

Treatment: In both WellGen and ANDIS, insulin treatment (alone or in combination with OHAs) was most commonly prescribed to SIDD patients (38.3\% in WellGen, $39.5 \%$ in ANDIS). (Table 4).

Complications: In WellGen, we compared the prevalence of complications in the two major subtypes, SIDD and MOD. Small numbers in SIRD and MARD preclude comparison of complications in these subgroups. Retinopathy and nephropathy were most common in SIDD whereas neuropathy was more prevalent in MOD. Prevalence of macrovascular complications was similar in the two subtypes. Of the less common subgroups, SIRD had a high prevalence of retinopathy while MARD of nephropathy and macrovascular disease. (Table 4).

In the young ANDIS cohort, nephropathy (70.4\%) and retinopathy (44.4\%) prevalence were highest in SIRD whereas neuropathy was most common in SIDD. Consistent with previous findings, SIRD also showed the highest prevalence of CKD (47.1\%) while macroalbuminuria (14.9\%) was most common in MOD (Table 4).

\section{De novo clusters shows high degree of concordance with SIDD and MOD}

We also applied the de novo k-means clustering to assess the subgroups obtained in the Indian patients and compared them with those obtained using the previously published algorithm. Two was the optimum number of clusters (ESM Fig 2a); cluster 1 had a prevalence of $66.6 \%$ while cluster 2 had a prevalence of $33.4 \%$ (ESM table 2). Cluster 1 showed $88.8 \%$ concordance with SIDD (86.8\% in males, $92.4 \%$ in females) while cluster 2 had an overlap of $62.5 \%$ with MOD 
medRxiv preprint doi: https://doi.org/10.1101/2021.05.07.21256703; this version posted May 10, 2021. The copyright holder for this preprint (which was not certified by peer review) is the author/funder, who has granted medRxiv a license to display the preprint in perpetuity.

(83.9\% in males, $\sim 49.5 \%$ in females) (ESM Fig $2 b$ ).

Both clusters had the same cluster characteristics as seen using the centroid method, thereby providing a technical replication (ESM Table 2). The similarity also extended to complications rates, with nephropathy and retinopathy being prevalent in cluster 1 compared to cluster 2 whereas neuropathy was more prevalent in cluster 2 (ESM Table 3).

\section{Low prevalence of genetic type 1 diabetes in WellGen type 2 diabetes subgroups}

In the absence of GADA data, a previously established type 1 diabetes GRS [24] comprising 9 SNPs (ESM Table 4) which was validated in the Indian population [22] was applied to estimate the proportion of patients with autoimmune diabetes in a subset of the WellGen cohort (ESM Table 5). The GRS was associated with the positive control type 1 diabetic patients compared to SIDD and MOD. The same GRS did not associate with either SIDD or MOD compared to nondiabetic controls (ESM Table 6 and ESM Fig 3). The proportion of patients with GRS $\geq 90 \%$ and $80 \%$ scores was $\sim 5 \%$ and $28.7 \%$, respectively, in type 1 diabetes (positive controls) whereas $0 \%$ and $1.4 \%$ in SIDD, $0 \%$ and $4.7 \%$ in MOD, $0 \%$ and $1 \%$ in controls. The same GRS was associated with SAID in young ANDIS patients (beta=7.3 $\pm 0.72, \mathrm{p}<2 \times 10^{-16}$ ).

\section{Indian diabetes subgroups similar to subgroups in European cohort DIREVA with longer diabetes duration}

Given the difference in duration of diabetes in ANDIS and WellGen, we compared the WellGen subgroups with those in the Finnish cohort DIREVA $(n=420)$ with duration of diabetes 14.4 years (ESM Table 7). The differences in proportion of subgroups and cluster characteristics between WellGen and DIREVA were similar to those as between WellGen and ANDIS (ESM Table 8, ESM Fig 4).

\section{Subgroups of diabetes in other regions of India}

We applied the Swedish algorithm [2] to two studies from different geographical regions in India, Ahmedabad, Gujarat, Western India $(\mathrm{N}=187)$ and Dibrugarh, Assam, North-Eastern India $(\mathrm{N}=205)$ (ESM Table 9 - 12). Concordant to findings in WellGen, the Ahmedabad cohort had the highest proportion of SIDD patients (56.68\%) followed by MOD (33.15\%) and MARD $(10.16 \%)$. The similarity extended to the subgroup distributions in the two sexes: The proportion of SIDD was highest in males (61.59\%) while MOD in females (53.06\%) (ESM Table 10, ESM

Fig 5). The PHENOEINDY-2 cohort was the youngest and the thinnest cohort of all, the proportion of SIDD (66.66\%) was the highest, followed by MOD (23.20\%), MARD (7.72\%) 
medRxiv preprint doi: https://doi.org/10.1101/2021.05.07.21256703; this version posted May 10, 2021. The copyright holder for this preprint (which was not certified by peer review) is the author/funder, who has granted medRxiv a license to display the preprint in perpetuity.

and SIRD (1.40\%) (ESM Table 12, ESM Fig 6).

\section{Discussion}

We showed that the clusters described in the newly diagnosed unselected European type 2 diabetes patients $[2,3]$ are also seen in the younger and thinner Indians. SIDD and MOD were the two predominant subgroups, while MARD was less common and SIRD the least common in both populations. SIDD was the predominant cluster in Indians whereas MOD in Europeans. The predominance of SIDD was replicated in two independent, geographically distinct Indian cohorts of patients with young onset type 2 diabetes.

The distribution of the clusters suggests that deficient insulin secretion, rather than the oftenpurported insulin resistance, is the driver of young type 2 diabetes in India. In contrast, in the young Swedish and Finnish type 2 diabetes patients, obesity and insulin resistance seemed to be the primary pathophysiological drivers. The proposed prominent role of insulin resistance was based on previous demonstrations of higher insulin resistance in Indians compared to Europeans at a given BMI possibly due to relatively more adipose body composition [7, 26, 27]. Despite the differences in age, BMI and duration of diabetes, the characteristics of the clusters themselves in Indians broadly reflected those in the European studies [2] Our new findings suggest a paradigm shift for the understanding of the pathophysiology of type 2 diabetes in young Indians, albeit they do not preclude the role of insulin resistance.

De novo k-means subclassification validated the two major subgroups obtained from the European derived centroids. The concordance was greater in the men for both subgroups, while, it was lower in women for the newly obtained cluster 2 with MOD. While, this increases our confidence in the classification, reclassification of a proportion of MOD women to a SIDD equivalent cluster 1 highlights the role of insulin deficiency in the pathogenesis of type 2 diabetes in young Indians.

We applied the European derived centroids to two smaller cohorts of young type 2 diabetes patients from western (Ahmedabad, Gujarat) and north-eastern (Dibrugarh, Assam) India. The proportion of subclasses in Ahmedabad patients was nearly identical to those in Pune while the proportion of SIDD patients was highest in Dibrugarh. Gujarat is a more affluent state while Assam has a lower development index and high prevalence of undernutrition.

Physicians in India have long realized the phenotypic differences of Indian diabetes patients 
medRxiv preprint doi: https://doi.org/10.1101/2021.05.07.21256703; this version posted May 10, 2021. The copyright holder for this preprint (which was not certified by peer review) is the author/funder, who has granted medRxiv a license to display the preprint in perpetuity.

All rights reserved. No reuse allowed without permission.

compared to those described in patients of European origin [28, 29]. Interestingly, the lean type 2 diabetes has been prominently reported from impoverished states of Orissa and north-east India, where malnutrition related diabetes (MRDM) was described [30]. A proportion of SIDD patients from Assam could well be characterised similarly. There is an increasing recognition that early life undernutrition could lead to smaller beta-cell mass and insulin secretion defects demonstrable from early childhood in serially studied birth cohorts and manifest as pre-diabetes or type 2 diabetes in young adulthood [31,32]. Animal studies have clearly demonstrated poor beta-cell development and islet dysfunction in the offspring born to malnourished pregnant mothers [33-35]. It is intriguing that the highest rise in the prevalence of type 2 diabetes in India over the last 25 years has been demonstrated in states which have suffered chronic environmental, socioeconomic and nutritional deficits [36]. On such a background of intergenerational deprivation, a relatively small socioeconomic development appears enough to precipitate diabetes at young age. It is of note that the prevalence of diabetes in those above 20 years of age has increased from 5.5 to $7.5 \%$ between 1990 and 2016 in the state of Assam.

The subgroups had different sensitivities to micro- and macrovascular complications. Microvascular affection in retina and kidney was more prevalent in SIDD compared to MOD while peripheral nerve affection was more prevalent in MOD. Possible reasons for these differences may lie in the pathophysiological mechanisms driving the subgroups which need to be studied further. Macrovascular disease was similar in two subgroups. In the original Swedish classification, SIRD subgroup generated lot of interest given their high propensity to develop nephropathy. It was the smallest subgroup in Indians with high insulin resistance as well as insulin secretion, however, was heterogeneous between the Indian cohorts. Intriguingly, MARD subgroup had a strikingly high rate of Macrovascular disease. The unique profiles of these subgroups could well represent population-specific differences and highlight the need for customisation of the clustering algorithm.

Other studies have investigated the heterogeneity of type 2 diabetes in Indians: The INSPIRED study from a chain of private diabetes clinics in India reported four subclasses, two of which were similar to the Swedish study (SIDD and MARD) [5], and two were new (insulin resistant obese diabetes - IROD and combined insulin resistance and deficient diabetes - CIRDD) [14]. However, the clustering parameters were different and therefore not directly comparable with our study. The MASALA-MESA study reported subclasses in a mixed population in the USA including migrant South Asian Indians $(n=217)$. They found an excess of younger, thinner and 
medRxiv preprint doi: https://doi.org/10.1101/2021.05.07.21256703; this version posted May 10, 2021. The copyright holder for this preprint (which was not certified by peer review) is the author/funder, who has granted medRxiv a license to display the preprint in perpetuity.

All rights reserved. No reuse allowed without permission.

severely hyperglycemic patients in the South Asian Indians supporting our findings [15].

Strengths and limitations: This is the first attempt in India to subclassify patients with a diagnosis of type 2 diabetes at a young age. The presence of comparable subgroups in our study to a genetically and historically distinct European population validates the subgroups. While the power of the study is limited, validation by de novo clustering increases confidence in classification. The Indian patients are clinic-based and enrolled many years after diagnosis while on antidiabetic treatment which may affect the proportions of subclasses. We cannot rule out the possibility that some patients might shift to different subgroups over time, but only a small proportion did so in another study [3]. A sensitivity analysis in WellGen showed that the proportions varied with increasing duration, however, SIDD (45.5\%) remained the predominant subgroup even in those with less than 5 years of diagnosis. Observations in other two Indian cohorts further validated these findings. Another limitation is that this study is an opportunistic comparison of existing data and therefore laboratory measurements are not fully harmonized between cohorts. However, C-peptide measurements in different cohorts were calibrated against the same WHO standard, facilitating comparisons. Given the lack of GAD antibody data, it might be suspected that the SIDD group in WellGen includes patients with autoimmune diabetes (Latent Autoimmune Diabetes in Adults: LADA). However, the low prevalence of individuals with high type 1 diabetes GRS scores in the WellGen deems a large contribution of autoimmune diabetes extremely unlikely.

In summary, we demonstrate applicability of a European algorithm for subclassifying type 2 diabetes in young Indian patients. Our results demonstrate a prominent role for insulin secretion defects in the pathophysiology of diabetes in this group. These results have a potential to influence treatment strategies to achieve optimal metabolic control with possible benefits for long-term health $[4,37]$. Translation to personalised medicine will come from carefully designed prospective studies including genetic and epigenetic investigations to elucidate pathophysiological mechanisms underlying the subgroups. 
medRxiv preprint doi: https://doi.org/10.1101/2021.05.07.21256703; this version posted May 10, 2021. The copyright holder for this preprint (which was not certified by peer review) is the author/funder, who has granted medRxiv a license to display the preprint in perpetuity.

\section{Author Contributions}

RBP, CSY, and LG contributed to the conception of the work. CSY, SRS and DB contributed to data collection in India, RBP, EA, OA, and LG in Sweden, and AK and TT in Finland. RPB, OA, SRS, EA, RW and PK contributed to the data analysis. RBP, CSY and LG drafted the article. All authors contributed to the interpretation of data and critical revision of the article. All authors gave final approval of the version to be published. RBP and CSY are the guarantors of this work and, as such, had full access to all the data in the study and takes responsibility for the integrity of the data and the accuracy of the data analysis.

\section{Declaration of interests}

We declare no competing interests.

\section{Acknowledgments}

This study was supported by grants from the Indo-Swedish joint network grant from the Swedish Research Council and the Department of Science and Technology, India (Dnr/Reg. nr: 201506722) to RBP and C/3019/IFD/2018-2019 to CSY, Wellcome Trust to CSY, Swedish Research Council (2017-02688), Diabetes Wellness Sweden (25-420 PG) and the Novo Nordisk Foundation (NNF18OC0034408) to EA, Swedish Research Foundation (2015-2558) to LG, the Swedish Heart and Lung Foundation, the Crafoord Foundation, the Swedish Diabetes Foundation and the Albert Påhlsson Research Foundation. The DIREVA Study is supported by the Vasa Hospital district, The Academy of Finland (grants no. 263401, 267882, 312063 to LG, 312072 to TT), University of Helsinki, Ollqvist Foundation, Finnish Diabetes Research Foundation, Helsinki University Central Hospital Research Foundation, Jakobstadsnejdens heart foundation to AK. CSY was a visiting Professor to Danish Diabetes Academy (supported by Novo Nordisk Foundation) and Southern University of Denmark during 2016-1019.

We thank all patients and health-care providers for their support and willingness to participate.

We thank Prof Andrew Hattersley, Dr Giriraj Chandak, Dr Shailaja Kale, Dr Sardeshmukh, Dr Meenakumari, Mrs Pallavi Yajnik, Ms Rasika Ladkat, Ms Deepa Raut, Ms Madhura Deshmukh, Ms Chitra Hole for their invaluable contribution to the WellGen Study. We gratefully acknowledge Jacqueline Postma, Johan Hultman, Jasmina Kravic, Gabriella Gremsperger, Ylva Wessman and Ulrika Blom-Nilsson for excellent technical and administrative support; and the ANDIS steering committee for their support. 
medRxiv preprint doi: https://doi.org/10.1101/2021.05.07.21256703; this version posted May 10, 2021. The copyright holder for this preprint (which was not certified by peer review) is the author/funder, who has granted medRxiv a license to display the preprint in perpetuity.

All rights reserved. No reuse allowed without permission.

\section{References}

[1] (1985) Diabetes mellitus. Report of a WHO Study Group. World Health Organ Tech Rep Ser 727: 1-113

[2] Ahlqvist E, Storm P, Karajamaki A, et al. (2018) Novel subgroups of adult-onset diabetes and their association with outcomes: a data-driven cluster analysis of six variables. Lancet Diabetes Endocrinol 6: 361-369

[3] Zaharia OP, Strassburger K, Strom A, et al. (2019) Risk of diabetes-associated diseases in subgroups of patients with recent-onset diabetes: a 5-year follow-up study. Lancet Diabetes Endocrinol 7: 684-694

[4] Prasad RB, Groop L (2019) Precision medicine in type 2 diabetes. J Intern Med 285: $40-48$

[5] Ahlqvist E, Prasad RB, Groop L (2020) Subtypes of Type 2 Diabetes Determined From Clinical Parameters. Diabetes 69: 2086-2093

[6] Shelgikar KM, Hockaday TD, Yajnik CS (1991) Central rather than generalized obesity is related to hyperglycaemia in Asian Indian subjects. Diabet Med 8: 712-717

[7] Yajnik CS (2001) The insulin resistance epidemic in India: fetal origins, later lifestyle, or both? Nutr Rev 59: 1-9

[8] Yajnik CS, Yudkin JS (2004) The Y-Y paradox. Lancet 363: 163

[9] Narayan KMV, Kondal D, Daya N, et al. (2021) Incidence and pathophysiology of diabetes in South Asian adults living in India and Pakistan compared with US blacks and whites. BMJ Open Diabetes Res Care 9

[10] Narayan KMV, Kanaya AM (2020) Why are South Asians prone to type 2 diabetes? A hypothesis based on underexplored pathways. Diabetologia 63: 1103-1109

[11] Watts G (2017) Lalit Dandona: surveying the burden of disease in India. Lancet 390: 2428

[12] Anjana RM, Deepa M, Pradeepa R, et al. (2017) Prevalence of diabetes and prediabetes in 15 states of India: results from the ICMR-INDIAB population-based cross-sectional study. Lancet Diabetes Endocrinol 5: 585-596

[13] Samal KC, Tripathy BB (1987) Malnutrition related diabetes. J Assoc Physicians India 35: 170

[14] Anjana RM, Baskar V, Nair ATN, et al. (2020) Novel subgroups of type 2 diabetes and their association with microvascular outcomes in an Asian Indian population: a data-driven cluster analysis: the INSPIRED study. BMJ Open Diabetes Res Care 8

[15] Bancks MP, Bertoni AG, Carnethon M, et al. (2021) Association of Diabetes Subgroups With Race/Ethnicity, Risk Factor Burden and Complications: The MASALA and MESA Studies. J Clin Endocrinol Metab

[16] Ministry of Health and Family Welfare (MoHFW) GoI, UNICEF, (CNNS) aPCCNNS, Delhi. NRN (2016-2018) Comprehensive National Nutrition Survey. https://nhmgovin [17] Golden SH, Yajnik C, Phatak S, Hanson RL, Knowler WC (2019) Racial/ethnic differences in the burden of type 2 diabetes over the life course: a focus on the USA and India. Diabetologia 62: 1751-1760

[18] Chandak GR, Janipalli CS, Bhaskar S, et al. (2007) Common variants in the TCF7L2 gene are strongly associated with type 2 diabetes mellitus in the Indian population.

Diabetologia 50: 63-67

[19] Yajnik CS, Joglekar CV, Lubree HG, et al. (2008) Adiposity, inflammation and hyperglycaemia in rural and urban Indian men: Coronary Risk of Insulin Sensitivity in Indian Subjects (CRISIS) Study. Diabetologia 51: 39-46

[20] Matthews DR, Hosker JP, Rudenski AS, Naylor BA, Treacher DF, Turner RC (1985) Homeostasis model assessment: insulin resistance and beta-cell function from fasting plasma glucose and insulin concentrations in man. Diabetologia 28: 412-419 
medRxiv preprint doi: https://doi.org/10.1101/2021.05.07.21256703; this version posted May 10, 2021. The copyright holder for this preprint (which was not certified by peer review) is the author/funder, who has granted medRxiv a license to display the preprint in perpetuity.

All rights reserved. No reuse allowed without permission.

[21] Levy JC, Matthews DR, Hermans MP (1998) Correct homeostasis model assessment (HOMA) evaluation uses the computer program. Diabetes Care 21: 2191-2192

[22] Harrison JW, Tallapragada DSP, Baptist A, et al. (2020) Type 1 diabetes genetic risk score is discriminative of diabetes in non-Europeans: evidence from a study in India. Sci Rep 10: 9450

[23] Rao S, Yajnik CS, Kanade A, et al. (2001) Intake of micronutrient-rich foods in rural Indian mothers is associated with the size of their babies at birth: Pune Maternal Nutrition Study. J Nutr 131: 1217-1224

[24] Oram RA, Patel K, Hill A, et al. (2016) A Type 1 Diabetes Genetic Risk Score Can Aid Discrimination Between Type 1 and Type 2 Diabetes in Young Adults. Diabetes Care 39: 337344

[25] Winkler C, Krumsiek J, Buettner F, et al. (2014) Feature ranking of type 1 diabetes susceptibility genes improves prediction of type 1 diabetes. Diabetologia 57: 2521-2529

[26] Sharp PS, Mohan V, Levy JC, Mather HM, Kohner EM (1987) Insulin resistance in patients of Asian Indian and European origin with non-insulin dependent diabetes. Horm Metab Res 19: 84-85

[27] Ramachandran A, Snehalatha C, Viswanathan V, Viswanathan M, Haffner SM (1997)

Risk of noninsulin dependent diabetes mellitus conferred by obesity and central adiposity in different ethnic groups: a comparative analysis between Asian Indians, Mexican Americans and Whites. Diabetes Res Clin Pract 36: 121-125

[28] Ramachandran A, Snehalatha, C. (2014) Epidemiology of Diabetes in Developing Countries: The Scenario in Asia. In: Chandalia HB (ed) RSSDI - Text Book of Diabetes Mellitus. Jaypee Brothers Medical Publishers, New Delhi, pp 171-180

[29] Das S, Panda, JK. (2014) Islets B Cell Response and Glucose Homeostasis in Low Body Weight Type 2 Diabetes. Journal of Diabetes and Metabolism 5

[30] Rao RH, Yajnik CS (1996) Commentary: time to rethink malnutrition and diabetes in the tropics. Diabetes Care 19: 1014-1017

[31] Memane NS, Bhat D, Raut DA, et al. (2018) Pregnancy Glycemia Reflects Life Course Glycemia of the Mother. Diabetes 67: 118-OR

[32] India State-Level Disease Burden Initiative Malnutrition C (2019) The burden of child and maternal malnutrition and trends in its indicators in the states of India: the Global Burden of Disease Study 1990-2017. Lancet Child Adolesc Health

[33] Snoeck A, Remacle C, Reusens B, Hoet JJ (1990) Effect of a low protein diet during pregnancy on the fetal rat endocrine pancreas. Biol Neonate 57: 107-118

[34] Fernandez-Twinn DS, Wayman A, Ekizoglou S, Martin MS, Hales CN, Ozanne SE (2005) Maternal protein restriction leads to hyperinsulinemia and reduced insulin-signaling protein expression in 21-mo-old female rat offspring. Am J Physiol Regul Integr Comp Physiol 288: R368-373

[35] Kumar KA, Lalitha A, Reddy U, Chandak GR, Sengupta S, Raghunath M (2014) Chronic maternal vitamin B12 restriction induced changes in body composition \& glucose metabolism in the Wistar rat offspring are partly correctable by rehabilitation. PLoS One 9: e112991

[36] India State-Level Disease Burden Initiative C (2017) Nations within a nation: variations in epidemiological transition across the states of India, 1990-2016 in the Global Burden of Disease Study. Lancet 390: 2437-2460

[37] Prasad RB, Ahlqvist E, Groop L (2019) Heterogeneity of diabetes - An Indian perspective. Diabetes Metab Syndr 13: 3065-3067 
medRxiv preprint doi: https://doi.org/10.1101/2021.05.07.21256703; this version posted May 10, 2021. The copyright holder for this preprint (which was not certified by peer review) is the author/funder, who has granted medRxiv a license to display the preprint in perpetuity.

All rights reserved. No reuse allowed without permission.

Tables

\begin{tabular}{|c|c|c|c|c|c|c|c|c|c|}
\hline \multirow[b]{2}{*}{ Characteristics } & \multicolumn{3}{|c|}{ WellGen } & \multicolumn{3}{|c|}{ ANDIS } & \multicolumn{3}{|c|}{ WellGen vs ANDIS } \\
\hline & Male & Female & All & Male & Female & All & P (males) & $\begin{array}{c}\mathbf{P} \\
\text { (females) }\end{array}$ & $P$ (all) \\
\hline Number & 902 & 710 & 1612 & 567 & 395 & 962 & & & \\
\hline Age at Diagnosis (y) & $\begin{array}{l}37.39 \\
(5.58) \\
\end{array}$ & $\begin{array}{l}36.47 \\
(5.99)\end{array}$ & $\begin{array}{l}39.98 \\
(5.78)\end{array}$ & $\begin{array}{c}39.13 \\
(5.8)\end{array}$ & $\begin{array}{c}38.4 \\
(6.16) \\
\end{array}$ & $\begin{array}{l}38.83 \\
(5.96)\end{array}$ & $<0.0001$ & $<0.0001$ & $<0.0001$ \\
\hline $\operatorname{BMI}\left(\mathrm{Kg} / \mathrm{m}^{2}\right)$ & $\begin{array}{l}25.43 \\
(3.74)\end{array}$ & $\begin{array}{l}27.14 \\
(4.27) \\
\end{array}$ & $\begin{array}{l}26.18 \\
(4.07) \\
\end{array}$ & $\begin{array}{l}32.47 \\
(6.60) \\
\end{array}$ & $\begin{array}{l}33.66 \\
(7.30) \\
\end{array}$ & $\begin{array}{l}32.96 \\
(6.92) \\
\end{array}$ & $<0.0001$ & $<0.0001$ & $<0.0001$ \\
\hline Fasting glucose $(\mathrm{mmol} / \mathrm{L})$ & $\begin{array}{c}9.08 \\
(3.23)\end{array}$ & $\begin{array}{c}9.48 \\
(3.45)\end{array}$ & $\begin{array}{c}9.26 \\
(3.33)\end{array}$ & $\begin{array}{c}9.28 \\
(3.36)\end{array}$ & $\begin{array}{c}8.34 \\
(2.80)\end{array}$ & $\begin{array}{c}8.89 \\
(3.18)\end{array}$ & 0.23 & $<0.0001$ & 0.007 \\
\hline $\mathrm{HbAlc}(\mathrm{mmol} / \mathrm{mol})$ & $\begin{array}{c}73.23 \\
(23.04) \\
\end{array}$ & $\begin{array}{c}71.62 \\
(22.19) \\
\end{array}$ & $\begin{array}{c}72.52 \\
(22.68) \\
\end{array}$ & $\begin{array}{c}75.09 \\
(25.55) \\
\end{array}$ & $\begin{array}{c}60.93 \\
(24.03) \\
\end{array}$ & $\begin{array}{c}69.28 \\
(25.88) \\
\end{array}$ & 0.16 & $<0.0001$ & 0.0008 \\
\hline Fasting C-peptide (nmol/L) & $\begin{array}{c}0.76 \\
(0.46)\end{array}$ & $\begin{array}{c}0.76 \\
(0.45) \\
\end{array}$ & $\begin{array}{c}0.76 \\
(0.46) \\
\end{array}$ & $\begin{array}{c}1.20 \\
(0.57) \\
\end{array}$ & $\begin{array}{c}1.97 \\
(0.56) \\
\end{array}$ & $\begin{array}{c}1.20 \\
(0.56) \\
\end{array}$ & $<0.0001$ & $<0.0001$ & $<0.0001$ \\
\hline HOMA2-B & $\begin{array}{c}58.7 \\
(40.28) \\
\end{array}$ & $\begin{array}{c}56.39 \\
(41.93) \\
\end{array}$ & $\begin{array}{c}57.69 \\
(41.02) \\
\end{array}$ & $\begin{array}{c}81.09 \\
(50.59) \\
\end{array}$ & $\begin{array}{c}88.36 \\
(45.48) \\
\end{array}$ & $\begin{array}{c}84.11 \\
(48.91) \\
\end{array}$ & $<0.0001$ & $<0.0001$ & $<\mathbf{0 . 0 0 0 1}$ \\
\hline HOMA2-IR & $\begin{array}{c}2.12 \\
(1.38) \\
\end{array}$ & $\begin{array}{c}2.15 \\
(1.35) \\
\end{array}$ & $\begin{array}{c}2.13 \\
(1.37) \\
\end{array}$ & $\begin{array}{c}3.27 \\
(1.62) \\
\end{array}$ & $\begin{array}{c}3.12 \\
(1.51) \\
\end{array}$ & $\begin{array}{l}3.21 \\
(1.58) \\
\end{array}$ & $<\mathbf{0 . 0 0 0 1}$ & $<0.0001$ & $<0.0001$ \\
\hline
\end{tabular}

Note: Values are mean (SD), pvalue calculated using t-test. Bonferroni corrected significant p-values are indicated in bold.

Table 1: Clinical and Biochemical characteristics of participants enrolled in WellGen and ANDIS study with age at diagnosis less than 45years. 


\begin{tabular}{|c|c|c|c|c|c|c|c|c|}
\hline & \multicolumn{3}{|c|}{ WellGen } & \multirow[b]{2}{*}{ p-value } & \multicolumn{3}{|c|}{ ANDIS } & \multirow[b]{2}{*}{ p-value } \\
\hline & Male (\%) & Female (\%) & Total (\%) & & Male (\%) & Female (\%) & Total (\%) & \\
\hline & $902(56.0)$ & $710(44.0)$ & 1612 & & $567(58.9)$ & 395 (41.1) & 962 & \\
\hline Duration of diabetes (y) & $9.73(8.57)$ & $9.70(7.74)$ & $9.72(8.21)$ & & $4.27(2.56)$ & $4.27(2.34)$ & $4.27(2.47)$ & \\
\hline \multicolumn{9}{|c|}{ Current treatment } \\
\hline Only on Diet & $77(8.5)$ & $58(8.2)$ & $135(8.4)$ & 0.348 & $34(6.0)$ & $43(10.9)$ & $77(8.0)$ & 0.006 \\
\hline Only on OHA & $558(61.9)$ & $421(59.3)$ & $979(60.7)$ & & $382(67.4)$ & $247(62.5)$ & $629(65.4)$ & 0.121 \\
\hline Only on Insulin & $51(5.7)$ & $34(4.8)$ & $85(5.3)$ & & $28(4.9)$ & $31(7.8)$ & $59(6.1)$ & 0.064 \\
\hline Both OHA+ Insulin & $216(23.9)$ & $197(27.7)$ & $413(25.6)$ & & $122(21.5)$ & $72(18.2)$ & $194(20.2)$ & 0.211 \\
\hline \multicolumn{9}{|c|}{ Complications } \\
\hline Cardiovascular disease & $106(11.7)$ & $40(4.4)$ & $146(9.1)$ & 0.0001 & $27(48)$ & $7(1.8)$ & $34(3.6)$ & 0.013 \\
\hline Coronary Events & $89(9.9)$ & $31(4.4)$ & $120(7.4)$ & 0.0001 & $19(3.3)$ & $4(1.0)$ & $23(2.4)$ & 0.019 \\
\hline Stroke & $17(1.9)$ & $9(1.3)$ & $26(1.7)$ & 0.199 & $8(1.4)$ & $3(0.8)$ & $11(1.2)$ & 0.348 \\
\hline $\begin{array}{l}\text { Nephropathy (Proteinuria and / or } \\
\text { CKD) }\end{array}$ & $361(40.0)$ & $200(28.2)$ & $561(34.8)$ & 0.0001 & $181(45.9)$ & $129(45.7)$ & $310(45.9)$ & 0.960 \\
\hline Macroalbuminuria $^{1}$ & $167(19.2)$ & $83(12.3)$ & $250(16.2)$ & 0.0001 & $61(17.1)$ & $29(11.4)$ & $90(14.7)$ & 0.047 \\
\hline CKD: e-Glomerular Filtration Rate*2 & $268(32.3)$ & $145(22.7)$ & $413(28.1)$ & 0.0001 & $142(26.0)$ & $109(28.7)$ & $251(27.1)$ & 0.359 \\
\hline Early CKD (60-90) & $208(25.0)$ & $122(19.1)$ & $330(22.4)$ & 0.0001 & $132(24.6)$ & $105(27.9)$ & $237(26.0)$ & 0.257 \\
\hline Moderate (30-60) & $54(6.5)$ & $20(3.1)$ & $74(5.0)$ & & $7(1.3)$ & $4(1.1)$ & $11(1.2)$ & 0.747 \\
\hline Severe $(<30)$ & $6(0.7)$ & $3(0.5)$ & $9(0.6)$ & & $3(0.5)$ & $0(0.0)$ & $3(0.3)$ & 0.148 \\
\hline Diabetic Retinopathy $(n=657)^{3}$ & $102(29.4)$ & $78(25.2)$ & $180(27.4)$ & 0.225 & $34(19.4)$ & $23(20.0)$ & $57(19.7)$ & 0.905 \\
\hline NPDR & $93(26.8)$ & $74(23.9)$ & $167(25.4)$ & 0.307 & $33(19.0)$ & $22(19.3)$ & $55(19.1)$ & 0.944 \\
\hline PDR & $9(2.6)$ & $4(1.3)$ & $13(2.0)$ & & $1(0.6)$ & $1(0.9)$ & $2(0.7)$ & 0.764 \\
\hline Neuropathy ${ }^{4}$ & $359(40.7)$ & $351(50.6)$ & $710(45.1)$ & 0.0001 & $14(2.5)$ & $2(0.5)$ & $16(1.7)$ & 0.019 \\
\hline
\end{tabular}

Values are number (\%), * Based on MDRD formula, p-value by Chi-square test. Bonferroni corrected significant p-values are indicated in bold.

1. Data available for $n=1020$ for WellGen, $n=618$ for ANDIS

2. $n=1039$ for WellGen and $n=938$ for ANDIS

3. $n=441$ for WellGen and $n=297$ for ANDIS

4. $n=1031$, Neuropathy diagnosed using Biothesiometry for WellGen, ICD codes ICD $10=$ E104 or E114 for ANDIS

Table 2: Complications and current treatment by gender for participants of the WellGen and ANDIS Studies 


\begin{tabular}{|c|c|c|c|c|c|c|c|c|c|c|c|c|c|c|}
\hline \multirow{3}{*}{$\begin{array}{l}\text { Gender } \\
\text { Cluster }\end{array}$} & \multicolumn{6}{|c|}{ WellGen } & \multicolumn{6}{|c|}{ ANDIS } & \multicolumn{2}{|c|}{ WellGen vs ANDIS } \\
\hline & \multicolumn{6}{|c|}{ All (1612) } & \multicolumn{6}{|c|}{ All (962) } & \multirow[b]{2}{*}{ p: SIDD } & \multirow[b]{2}{*}{ p:MOD } \\
\hline & SIDD & SIRD & MOD & MARD & $\mathbf{p}$ & p1 & SIDD & SIRD & MOD & MARD & $\mathbf{p}$ & p1 & & \\
\hline Number & $\begin{array}{c}851 \\
(52.79) \\
\end{array}$ & $\begin{array}{c}18 \\
(1.11) \\
\end{array}$ & $\begin{array}{c}608 \\
(37.71) \\
\end{array}$ & $\begin{array}{c}135 \\
(8.37) \\
\end{array}$ & & & $\begin{array}{c}251 \\
(26.09) \\
\end{array}$ & $\begin{array}{c}35 \\
(3.64) \\
\end{array}$ & $\begin{array}{c}650 \\
(67.56) \\
\end{array}$ & $\begin{array}{c}26 \\
(2.7) \\
\end{array}$ & & & & \\
\hline Age at Diagnosis (y) & $\begin{array}{l}36.86 \\
(5.81) \\
\end{array}$ & $\begin{array}{l}38.83 \\
(4.93) \\
\end{array}$ & $\begin{array}{l}36.25 \\
(5.77) \\
\end{array}$ & $\begin{array}{l}40.84 \\
(3.98) \\
\end{array}$ & 0.005 & 0.0001 & $\begin{array}{l}38.98 \\
(6.24) \\
\end{array}$ & $\begin{array}{l}39.94 \\
(5.87) \\
\end{array}$ & $\begin{array}{c}38.56 \\
(5.9) \\
\end{array}$ & $\begin{array}{c}42.5 \\
(2.79) \\
\end{array}$ & $<0.0001$ & $<0.0001$ & $<0.0001$ & $<0.0001$ \\
\hline Duration of diabetes (y) & $\begin{array}{l}10.49 \\
(8.25)\end{array}$ & $\begin{array}{c}6.41 \\
(7.16)\end{array}$ & $\begin{array}{c}8.72 \\
(8.03) \\
\end{array}$ & $\begin{array}{c}9.83 \\
(8.44) \\
\end{array}$ & 0.001 & -- & -- & - & -- & -- & -- & - & -- & -- \\
\hline $\mathrm{BMI}\left(\mathrm{Kg} / \mathrm{m}^{2}\right)$ & $\begin{array}{l}25.02 \\
(3.45)\end{array}$ & $\begin{array}{l}28.37 \\
(5.27)\end{array}$ & $\begin{array}{l}28.4 \\
(4.03)\end{array}$ & $\begin{array}{l}23.22 \\
(2.44)\end{array}$ & 0.0001 & 0.0001 & $\begin{array}{l}28.29 \\
(5.43) \\
\end{array}$ & $\begin{array}{l}36.62 \\
(6.28)\end{array}$ & $\begin{array}{l}34.92 \\
(6.41) \\
\end{array}$ & $\begin{array}{l}24.11 \\
(2.33)\end{array}$ & $<0.0001$ & $<0.0001$ & $<0.0001$ & $<0.0001$ \\
\hline Fasting glucose ( mmol/L) & $\begin{array}{l}10.77 \\
(3.39)\end{array}$ & $\begin{array}{c}6.86 \\
(1.89)\end{array}$ & $\begin{array}{c}7.85 \\
(2.37) \\
\end{array}$ & $\begin{array}{c}6.50 \\
(1.47)\end{array}$ & 0.0001 & 0.0001 & $\begin{array}{l}11.75 \\
(3.67) \\
\end{array}$ & $\begin{array}{c}7.05 \\
(2.22) \\
\end{array}$ & $\begin{array}{c}7.97 \\
(2.25) \\
\end{array}$ & $\begin{array}{c}6.75 \\
(1.26) \\
\end{array}$ & $<0.0001$ & $<0.0001$ & $<0.0001$ & 0.06 \\
\hline HbAlc (mmol/mol) & $\begin{array}{l}87.01 \\
(19.34)\end{array}$ & $\begin{array}{c}56.7 \\
(13.1)\end{array}$ & $\begin{array}{c}58.33 \\
(12.92) \\
\end{array}$ & $\begin{array}{c}47.25 \\
(10.37) \\
\end{array}$ & 0.0001 & 0.0001 & $\begin{array}{c}100.6 \\
(19.62)\end{array}$ & $\begin{array}{c}55.19 \\
(13.79) \\
\end{array}$ & $\begin{array}{c}58.87 \\
(17.64) \\
\end{array}$ & $\begin{array}{l}45.85 \\
(7.41) \\
\end{array}$ & $<0.0001$ & $<0.0001$ & $<0.0001$ & 0.53 \\
\hline Fasting C-Peptide (nmol/L) & $\begin{array}{c}0.68 \\
(0.39)\end{array}$ & $\begin{array}{c}1.01 \\
(0.62) \\
\end{array}$ & $\begin{array}{c}0.89 \\
(0.48) \\
\end{array}$ & $\begin{array}{c}0.58 \\
(0.29) \\
\end{array}$ & 0.0001 & 0.0001 & $\begin{array}{l}0.85 \\
(0.4) \\
\end{array}$ & $\begin{array}{c}2.53 \\
(0.61) \\
\end{array}$ & $\begin{array}{c}1.29 \\
(0.48) \\
\end{array}$ & $\begin{array}{c}0.73 \\
(0.24) \\
\end{array}$ & $<0.0001$ & $<0.0001$ & $<0.0001$ & $<0.0001$ \\
\hline HOMA2B & $\begin{array}{c}37.66 \\
(22.24)\end{array}$ & $\begin{array}{l}214.99 \\
(41.01) \\
\end{array}$ & $\begin{array}{c}77.49 \\
(42.02) \\
\end{array}$ & $\begin{array}{l}73.74 \\
(31.16) \\
\end{array}$ & 0.0001 & 0.0001 & $\begin{array}{c}41.03 \\
(28.34) \\
\end{array}$ & $\begin{array}{l}968.71 \\
(56.43) \\
\end{array}$ & $\begin{array}{c}94.79 \\
(38.53) \\
\end{array}$ & $\begin{array}{c}80.15 \\
(27.62) \\
\end{array}$ & $<0.0001$ & $<0.0001$ & 0.048 & $<0.0001$ \\
\hline
\end{tabular}

\begin{tabular}{|c|c|c|c|c|c|c|c|c|c|c|c|c|c|c|}
\hline \multirow{2}{*}{$\begin{array}{l}\text { Gender } \\
\text { Cluster }\end{array}$} & \multicolumn{6}{|c|}{ Male (902) } & \multicolumn{6}{|c|}{ Male (567) } & \multirow[b]{2}{*}{ p: SIDD } & \multirow[b]{2}{*}{ p:MOD } \\
\hline & SIDD & SIRD & MOD & MARD & $\mathbf{p}$ & p1 & SIDD & SIRD & MOD & MARD & $\mathbf{p}$ & p1 & & \\
\hline Number & $\begin{array}{c}547 \\
(60.6)\end{array}$ & $\begin{array}{c}5 \\
(0.55) \\
\end{array}$ & $\begin{array}{c}230 \\
(25.49)\end{array}$ & $\begin{array}{c}120 \\
(13.30)\end{array}$ & & & $\begin{array}{c}185 \\
(32.6) \\
\end{array}$ & $\begin{array}{c}16 \\
(2.82)\end{array}$ & $\begin{array}{c}345 \\
(60.84)\end{array}$ & $\begin{array}{c}21 \\
(3.7)\end{array}$ & & & & \\
\hline Age at Diagnosis (y) & $\begin{array}{l}36.96 \\
(5.67)\end{array}$ & $\begin{array}{l}42.07 \\
(10.27) \\
\end{array}$ & $\begin{array}{l}36.59 \\
(5.43) \\
\end{array}$ & $\begin{array}{c}40.7 \\
(4.12) \\
\end{array}$ & 0.0001 & 0.0001 & $\begin{array}{l}38.91 \\
(6.08)\end{array}$ & $\begin{array}{l}40.56 \\
(6.19)\end{array}$ & $\begin{array}{c}39.0 \\
(5.73)\end{array}$ & $\begin{array}{l}42.05 \\
(2.87)\end{array}$ & 0.08 & 0.089 & $<0.0001$ & $<0.0001$ \\
\hline Duration of diabetes (y) & $\begin{array}{l}10.55 \\
(8.70)\end{array}$ & $\begin{array}{c}8.03 \\
(6.59)\end{array}$ & $\begin{array}{c}7.71 \\
(7.98)\end{array}$ & $\begin{array}{c}9.98 \\
(8.56)\end{array}$ & 0.005 & -- & & & & & & & & \\
\hline $\operatorname{BMI}\left(\mathrm{Kg} / \mathrm{m}^{2}\right)$ & $\begin{array}{l}24.44 \\
(3.08)\end{array}$ & $\begin{array}{l}28.75 \\
(3.54)\end{array}$ & $\begin{array}{l}28.77 \\
(3.67)\end{array}$ & $\begin{array}{l}23.41 \\
(2.34)\end{array}$ & 0.0001 & 0.0001 & $\begin{array}{r}27.45 \\
(3.9) \\
\end{array}$ & $\begin{array}{l}36.74 \\
(6.01) \\
\end{array}$ & $\begin{array}{r}35.44 \\
(5.9) \\
\end{array}$ & $\begin{array}{l}24.72 \\
(2.11)\end{array}$ & $<0.0001$ & $<0.0001$ & $<0.0001$ & $<0.0001$ \\
\hline Fasting glucose ( mmol/L) & $\begin{array}{l}10.29 \\
(3.22) \\
\end{array}$ & $\begin{array}{l}5.75 \\
(1.0) \\
\end{array}$ & $\begin{array}{c}7.63 \\
(2.43) \\
\end{array}$ & $\begin{array}{c}6.52 \\
(1.53) \\
\end{array}$ & 0.0001 & 0.0001 & $\begin{array}{l}11.80 \\
(3.5) \\
\end{array}$ & $\begin{array}{c}7.58 \\
(3.04) \\
\end{array}$ & $\begin{array}{c}8.16 \\
(2.53) \\
\end{array}$ & $\begin{array}{c}6.77 \\
(2.53) \\
\end{array}$ & $<0.0001$ & $<0.0001$ & $<0.0001$ & 0.013 \\
\hline $\mathrm{HbAlc}(\mathrm{mmol} / \mathrm{mol})$ & $\begin{array}{c}84.67 \\
(20.57)\end{array}$ & $\begin{array}{c}49.07 \\
(10.27)\end{array}$ & $\begin{array}{c}59.94 \\
(13.35) \\
\end{array}$ & $\begin{array}{c}47.55 \\
(10.02) \\
\end{array}$ & 0,0001 & 0.0001 & $\begin{array}{c}99.58 \\
(20.31)\end{array}$ & $\begin{array}{c}57.33 \\
(13.82)\end{array}$ & $\begin{array}{c}64.59 \\
(18.46)\end{array}$ & $\begin{array}{l}45.30 \\
(7.11)\end{array}$ & $<0.0001$ & $<0.0001$ & $<0.0001$ & 0.001 \\
\hline Fasting C-Peptide (nmol/L) & $\begin{array}{c}0.66 \\
(0.38)\end{array}$ & $\begin{array}{c}2.17 \\
(0.44)\end{array}$ & $\begin{array}{c}1.08 \\
(0.51)\end{array}$ & $\begin{array}{c}0.60 \\
(0.30)\end{array}$ & 0.0001 & 0.0001 & $\begin{array}{c}0.82 \\
(0.35)\end{array}$ & $\begin{array}{c}2.65 \\
(0.61)\end{array}$ & $\begin{array}{c}1.36 \\
(0.49)\end{array}$ & $\begin{array}{c}0.72 \\
(0.49)\end{array}$ & $<0.0001$ & $<0.0001$ & $<0.0001$ & $<0.0001$ \\
\hline HOMA2B & $\begin{array}{l}39.33 \\
(22.5)\end{array}$ & $\begin{array}{l}229.16 \\
(40.98)\end{array}$ & $\begin{array}{c}92.27 \\
(42.49)\end{array}$ & $\begin{array}{c}75.58 \\
(31.92) \\
\end{array}$ & 0.0001 & 0.0001 & $\begin{array}{c}39.15 \\
(25.31) \\
\end{array}$ & $\begin{array}{l}200.56 \\
(74.37)\end{array}$ & $\begin{array}{c}98.19 \\
(40.98)\end{array}$ & $\begin{array}{c}78.57 \\
(27.41)\end{array}$ & $<0.0001$ & $<0.0001$ & 0.92 & 0.094 \\
\hline HOMA2IR & $\begin{array}{c}1.96 \\
(1.34) \\
\end{array}$ & $\begin{array}{l}4.99 \\
(1.23)\end{array}$ & $\begin{array}{c}2.76 \\
(1.41)\end{array}$ & $\begin{array}{c}1.47 \\
(0.78) \\
\end{array}$ & 0.092 & 0.0001 & $\begin{array}{c}2.59 \\
(1.27)\end{array}$ & $\begin{array}{l}6.67 \\
(2.23) \\
\end{array}$ & $\begin{array}{c}3.56 \\
(1.48)\end{array}$ & $1.77(0.65)$ & $<0.0001$ & $<0.0001$ & $<0.0001$ & $<0.0001$ \\
\hline
\end{tabular}




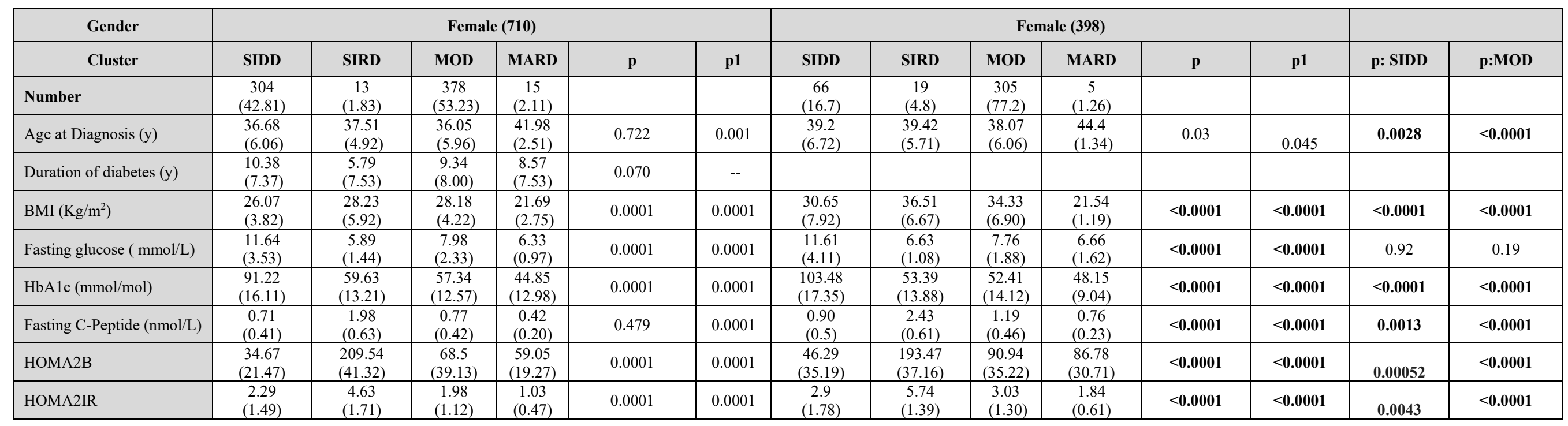

Note: Values are mean (SD), p-value by ANOVA, pl adjusted for duration of diabetes. Bonferroni corrected significant p-values are indicated in bold.

Table 3: Characteristics of participants enrolled in WellGen and ANDIS study by clusters for all participants, males and females. 


\begin{tabular}{|c|c|c|c|c|c|c|c|c|c|c|c|c|c|c|}
\hline & \multicolumn{7}{|c|}{ WellGen ( $N=1612)$} & \multicolumn{7}{|c|}{ ANDIS (N=962) } \\
\hline & SIDD & SIRD & MOD & MARD & $\begin{array}{c}\text { p- } \\
\text { value }\end{array}$ & $\begin{array}{c}\text { p1 } \\
\text { value }\end{array}$ & $\begin{array}{c}\text { p2 } \\
\text { value }\end{array}$ & SIDD & SIRD & MOD & MARD & $\begin{array}{c}\text { p- } \\
\text { value }\end{array}$ & $\begin{array}{c}\text { p1 } \\
\text { value }\end{array}$ & $\begin{array}{c}\text { p2 } \\
\text { value }\end{array}$ \\
\hline Number & 851 & 18 & 608 & 135 & & & & 251 & 35 & 650 & 26 & & & \\
\hline \multicolumn{15}{|l|}{ Current Treatment } \\
\hline Only on Diet & $\begin{array}{c}68 \\
(8.0) \\
\end{array}$ & $\begin{array}{c}4 \\
(22.2) \\
\end{array}$ & $\begin{array}{c}54 \\
(8.9) \\
\end{array}$ & $\begin{array}{c}9 \\
(6.7) \\
\end{array}$ & 0.0001 & 0.0001 & -- & $\begin{array}{c}4 \\
(1.1) \\
\end{array}$ & $\begin{array}{c}5 \\
(10.6)\end{array}$ & $\begin{array}{c}60 \\
(6.7) \\
\end{array}$ & $\begin{array}{c}8 \\
(23.5) \\
\end{array}$ & 0.0001 & 0.0001 & 0.002 \\
\hline $\begin{array}{l}\text { Only on OHA } \\
\text { (SUs+Metformin+/- } \\
\text { Glitazones) }\end{array}$ & $\begin{array}{r}457 \\
(53.7)\end{array}$ & $\begin{array}{r}13 \\
(72.2)\end{array}$ & $\begin{array}{r}409 \\
(67.3)\end{array}$ & $\begin{array}{r}100 \\
(74.1)\end{array}$ & & & & $\begin{array}{c}117 \\
(46.6)\end{array}$ & $\begin{array}{c}33 \\
(74.3)\end{array}$ & $\begin{array}{c}470 \\
(72.3)\end{array}$ & $\begin{array}{c}16 \\
(61.5)\end{array}$ & 0.0001 & 0.0001 & 0.0001 \\
\hline Only on Insulin & $\begin{array}{c}58 \\
(6.8) \\
\end{array}$ & -- & $\begin{array}{c}19 \\
(3.1)\end{array}$ & $\begin{array}{c}8 \\
(5.9) \\
\end{array}$ & & & & $\begin{array}{c}36 \\
(14.3)\end{array}$ & $\begin{array}{c}0 \\
(0)\end{array}$ & $\begin{array}{c}23 \\
(3.5)\end{array}$ & $\begin{array}{c}0 \\
(0)\end{array}$ & 0.0001 & 0.0001 & 0.0001 \\
\hline Both OHA+ Insulin ${ }^{1}$ & $\begin{array}{r}268 \\
(31.5) \\
\end{array}$ & $\begin{array}{c}1 \\
(5.6) \\
\end{array}$ & $\begin{array}{r}126 \\
(20.7) \\
\end{array}$ & $\begin{array}{c}18 \\
(13.3) \\
\end{array}$ & & & & $\begin{array}{c}92 \\
(25.2) \\
\end{array}$ & $\begin{array}{c}4 \\
(8.5) \\
\end{array}$ & $\begin{array}{c}96 \\
(10.7) \\
\end{array}$ & $\begin{array}{c}2 \\
(5.9) \\
\end{array}$ & 0.0001 & 0.0001 & 0.0001 \\
\hline \multicolumn{15}{|l|}{ Complications } \\
\hline Cardiovascular disease $^{2}$ & $\begin{array}{c}61 \\
(7.2) \\
\end{array}$ & -- & $\begin{array}{c}39 \\
(6.4) \\
\end{array}$ & $\begin{array}{c}20 \\
(14.8)\end{array}$ & 0.004 & 0.553 & 0.257 & $\begin{array}{c}10 \\
(4.0) \\
\end{array}$ & $\begin{array}{c}3 \\
(8.6) \\
\end{array}$ & $\begin{array}{c}20 \\
(3.1) \\
\end{array}$ & $\begin{array}{c}1 \\
(3.8) \\
\end{array}$ & 0.375 & 0.502 & 0.633 \\
\hline Coronary Events & $\begin{array}{c}51 \\
(6.0)\end{array}$ & -- & $\begin{array}{c}32 \\
(5.3)\end{array}$ & $\begin{array}{c}17 \\
(12.6)\end{array}$ & & & & $\begin{array}{c}7 \\
(2.8)\end{array}$ & $\begin{array}{c}3 \\
(8.6)\end{array}$ & $\begin{array}{c}13 \\
(2.0)\end{array}$ & $\begin{array}{c}0 \\
(0)\end{array}$ & 0.075 & 0.476 & 0.493 \\
\hline Stroke & $\begin{array}{c}13 \\
(1.6)\end{array}$ & -- & $\begin{array}{c}9 \\
(1.5)\end{array}$ & $\begin{array}{c}4 \\
(3.1) \\
\end{array}$ & & & & $\begin{array}{c}3 \\
(1.2) \\
\end{array}$ & $\begin{array}{c}0 \\
(0)\end{array}$ & $\begin{array}{c}7 \\
(1.1) \\
\end{array}$ & $\begin{array}{c}1 \\
(3.8) \\
\end{array}$ & 0.522 & 0.884 & 0.980 \\
\hline $\begin{array}{l}\text { Nephropathy } \\
\text { (Proteinuria and/or CKD) } \\
\text { (n=1612) }\end{array}$ & $\begin{array}{r}340 \\
(40.0)\end{array}$ & $\begin{array}{c}6 \\
(33.3)\end{array}$ & $\begin{array}{r}147 \\
(24.2)\end{array}$ & $\begin{array}{c}68 \\
(50.4)\end{array}$ & 0.0001 & 0.0001 & 0.0001 & $\begin{array}{c}76 \\
(40.0)\end{array}$ & $\begin{array}{c}19 \\
(70.4)\end{array}$ & $\begin{array}{c}206 \\
(46.6)\end{array}$ & $\begin{array}{c}9 \\
(52.9)\end{array}$ & 0.022 & 0.126 & 0.087 \\
\hline Macroalbuminuria $^{3}$ & $\begin{array}{r}172 \\
(21.1) \\
\end{array}$ & -- & $\begin{array}{r}66 \\
(11.3)\end{array}$ & $\begin{array}{c}12 \\
(9.4) \\
\end{array}$ & 0.0001 & 0.0001 & 0.001 & $\begin{array}{c}25 \\
(13.8)\end{array}$ & $\begin{array}{c}5 \\
(5.0) \\
\end{array}$ & $\begin{array}{c}59 \\
(14.9) \\
\end{array}$ & $\begin{array}{c}1 \\
(7.1) \\
\end{array}$ & 0.484 & 0.731 & 0.635 \\
\hline $\begin{array}{l}\text { CKD: e-Glomerular } \\
\text { Filtration Rate }{ }^{* 4}(n=1471)\end{array}$ & $\begin{array}{r}247 \\
(31.7)\end{array}$ & $\begin{array}{c}6 \\
(35.3)\end{array}$ & $\begin{array}{c}98 \\
(17.6)\end{array}$ & $\begin{array}{c}62 \\
(52.1)\end{array}$ & 0.0001 & 0.0001 & 0.0001 & $\begin{array}{c}62 \\
(25.4)\end{array}$ & $\begin{array}{c}16 \\
(47.1)\end{array}$ & $\begin{array}{l}165 \\
(26.4)\end{array}$ & $\begin{array}{c}8 \\
(33.3)\end{array}$ & 0.049 & 0.765 & 0.475 \\
\hline Early CKD (60-90) & $\begin{array}{r}190 \\
(24.4)\end{array}$ & $\begin{array}{c}6 \\
(35.3)\end{array}$ & $\begin{array}{r}85 \\
(15.3)\end{array}$ & $\begin{array}{r}49 \\
(41.2)\end{array}$ & & & & $\begin{array}{c}56 \\
(23.5)\end{array}$ & $\begin{array}{c}16 \\
(47.1)\end{array}$ & $\begin{array}{c}157 \\
(25.4)\end{array}$ & $\begin{array}{c}8 \\
(33.3)\end{array}$ & 0.025 & 0.561 & 0.831 \\
\hline Moderate (30-60) & $\begin{array}{c}52 \\
(6.7) \\
\end{array}$ & -- & $\begin{array}{c}10 \\
(1.8) \\
\end{array}$ & $\begin{array}{c}12 \\
(10.1)\end{array}$ & & & & $\begin{array}{c}5 \\
(2.1) \\
\end{array}$ & $\begin{array}{c}0 \\
(0)\end{array}$ & $\begin{array}{c}6 \\
(1.0) \\
\end{array}$ & $\begin{array}{c}0 \\
(0)\end{array}$ & 0.471 & 0.196 & 0.162 \\
\hline Severe $(<30)$ & $\begin{array}{c}5 \\
(0.6)\end{array}$ & -- & $\begin{array}{c}3 \\
(0.5) \\
\end{array}$ & $\begin{array}{c}1 \\
(0.8)\end{array}$ & & & & $\begin{array}{c}1 \\
(0.4)\end{array}$ & $\begin{array}{c}0 \\
(0)\end{array}$ & $\begin{array}{c}2 \\
(0.3)\end{array}$ & $\begin{array}{c}0 \\
(0)\end{array}$ & 0.970 & 0.893 & 0.935 \\
\hline
\end{tabular}




\begin{tabular}{|c|c|c|c|c|c|c|c|c|c|c|c|c|c|c|}
\hline $\begin{array}{l}\text { Diabetic Retinopathy } \\
(\mathbf{n}=657)^{5}\end{array}$ & $\begin{array}{r}112 \\
(36.8) \\
(\mathrm{n}=304)\end{array}$ & $\begin{array}{c}4 \\
(57.1) \\
(n=7)\end{array}$ & $\begin{array}{c}51 \\
(18.0) \\
(\mathrm{n}=284) \\
\end{array}$ & $\begin{array}{c}13 \\
(21.0) \\
(n=62)\end{array}$ & 0.0001 & 0.0001 & 0.0001 & $\begin{array}{c}23 \\
(24.7) \\
(\mathrm{N}=93) \\
\end{array}$ & $\begin{array}{c}4 \\
(44.4) \\
\\
(\mathrm{N}=9)\end{array}$ & $\begin{array}{c}30 \\
(16.6) \\
(\mathrm{N}=181)\end{array}$ & $\begin{array}{c}0 \\
(0) \\
(\mathrm{N}=7)\end{array}$ & 0.050 & 0.11 & 0.13 \\
\hline NPDR & $\begin{array}{r}105 \\
(34.5) \\
\end{array}$ & $\begin{array}{c}4 \\
(57.1) \\
\end{array}$ & $\begin{array}{r}46 \\
(16.2)\end{array}$ & $\begin{array}{c}12 \\
(19.4)\end{array}$ & & & & $\begin{array}{c}22 \\
(23.9)\end{array}$ & $\begin{array}{c}5 \\
(44.4)\end{array}$ & $\begin{array}{c}29 \\
(16.1)\end{array}$ & $\begin{array}{l}0 \\
(0)\end{array}$ & 0.050 & 0.050 & 0.225 \\
\hline PDR & $\begin{array}{c}7 \\
(2.3)\end{array}$ & 0 & $\begin{array}{c}5 \\
(1.8)\end{array}$ & $\begin{array}{c}1 \\
(1.6)\end{array}$ & & & & $\begin{array}{c}1 \\
(1.1)\end{array}$ & $\begin{array}{c}0 \\
(0)\end{array}$ & $\begin{array}{c}1 \\
(0.6)\end{array}$ & $\begin{array}{c}0 \\
(0)\end{array}$ & 0.948 & 0.948 & 0.821 \\
\hline Neuropathy ${ }^{6}$ & $\begin{array}{r}322 \\
(38.8)\end{array}$ & $\begin{array}{c}9 \\
(50.0)\end{array}$ & $\begin{array}{r}323 \\
(53.8)\end{array}$ & $\begin{array}{r}56 \\
(43.4)\end{array}$ & 0.0001 & 0.0001 & 0.003 & $\begin{array}{c}12 \\
(4.8)\end{array}$ & $\begin{array}{c}1 \\
(2.9)\end{array}$ & $\begin{array}{c}3 \\
(0.5)\end{array}$ & $\begin{array}{c}0 \\
(0)\end{array}$ & 0.0001 & 0.0001 & 0.002 \\
\hline
\end{tabular}

Values are number (\%). p-value by Chi-square test. * Based on MDRD formula. p1-value by Chi-square test for SIDD and MOD clusters only. P2-value by logistic regression adjusted for duration of diabetes and gender for SIDD and MOD clusters. Bonferroni corrected significant p-values are indicated in bold.

1. Data for metformin + insulin only for ANDIS clusters

2. $n=967$ for ANDIS

3. $n=1020$ for WellGen and $n=618$ for ANDIS

4. $n=1039$ for WellGen and $n=938$ for ANDIS

5. $n=441$ for WellGen and $n=297$ for ANDIS

6. $n=1031$, method $=$ Biothesiometry for WellGen. ICD10 = E104 or E114 for ANDIS

Table 4: Treatment and complications by cluster in the WellGen and ANDIS study 


\section{WellGen.}

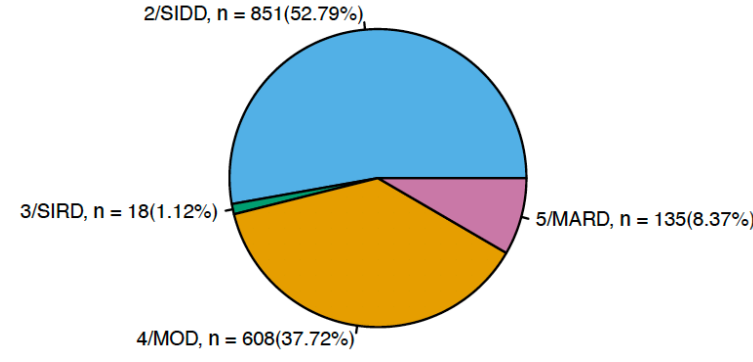

A

B

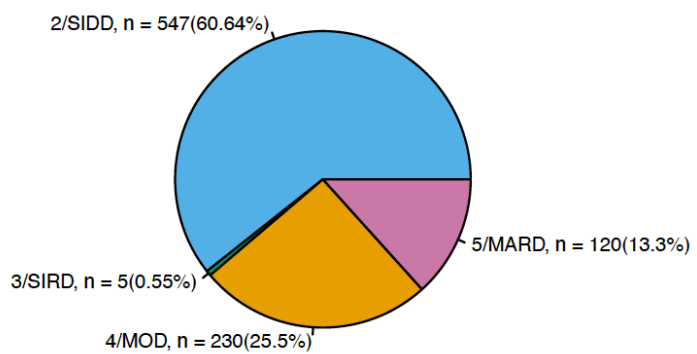

$4 / \mathrm{MOD}, \mathrm{n}=230(25.5 \%)$

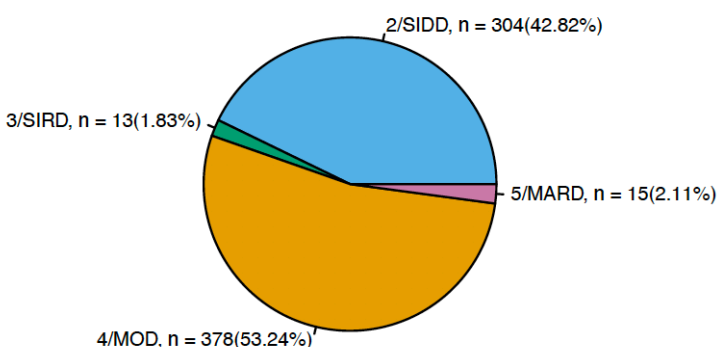

C

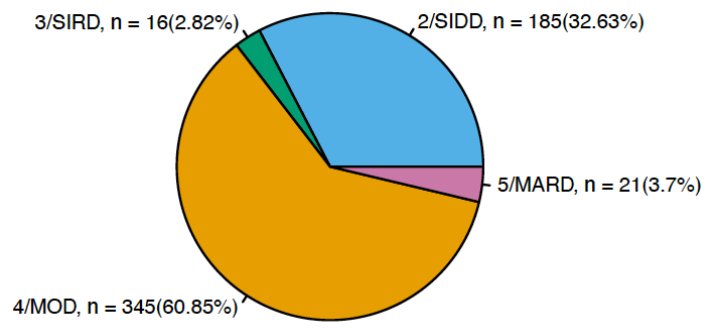

E

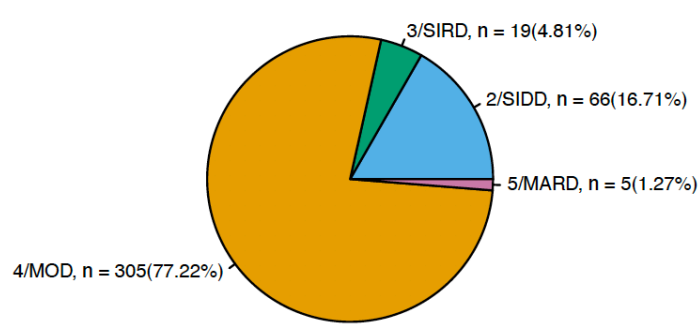

ALL

MALES

FEMALES

Figure 1. Distribution of participants from the WellGen and ANDIS study in the predefined clusters. (A) Distribution of WellGen patients ( $\mathrm{n}=1612)(B)$

distribution of men with diabetes from the WellGen study $(n=902)(C)$ distribution of women with diabetes from the WellGen study ( $n=710)(D)$ Distribution of ANDIS patients $(n=973)$ (E) distribution of men with diabetes from the ANDIS study $(n=575)(F)$ distribution of women with diabetes from the ANDIS study ( $n=$ 398) 

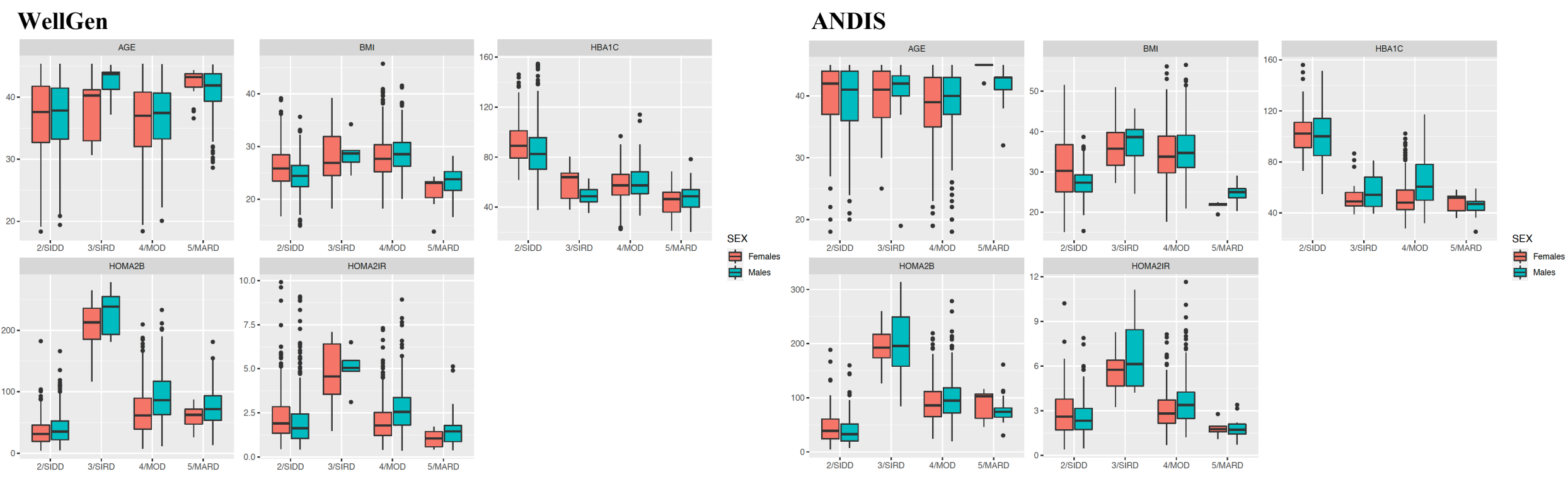

Figure 2. Cluster Characteristics in the WellGen and ANDIS studies. Distribution of age at diagnosis, BMI, HbA1c, HOMA2-B and HOMA2-IR in the WellGen and ANDIS studies for each cluster. k-means clustering was done separately for men and women; data is shown for each sex separately. $\mathrm{SIDD}=$ severe insulin-deficient diabetes, $\mathrm{SIRD}=$ resistant diabetes, $\mathrm{MOD}=$ mild obesity-related-related diabetes, $\mathrm{MARD}=$ mild age-related diabetes . HOMA2-B = homeostatic model assessment 2 estimates of beta cell function. HOMA2-B $=$ homeostatic model assessment 2 estimates insulin resistance. 
medRxiv preprint doi: https://doi.org/10.1101/2021.05.07.21256703; this version posted May 10, 2021. The copyright holder for this preprint (which was not certified by peer review) is the author/funder, who has granted medRxiv a license to display the preprint in perpetuity.

All rights reserved. No reuse allowed without permission. 